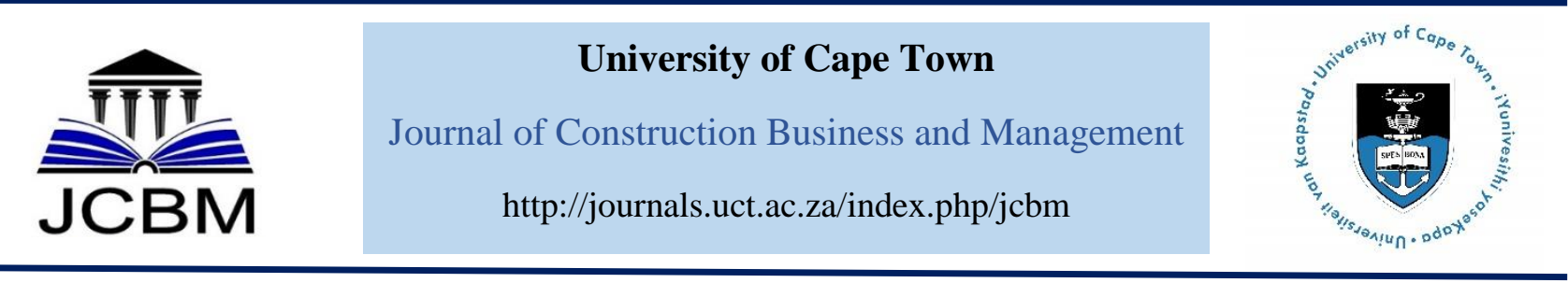

\title{
Drivers of Rural Housing Development in Edo State, Nigeria
}

\author{
T. T. Oladokun ${ }^{1}$, M. O. Komolafe ${ }^{2}$ \\ Department of Estate Management, Obafemi Awolowo University ${ }^{1}$ \\ Department of Estate Management, University of Benin ${ }^{2}$
}

Received 14 October 2016; received in revised form 4 January 2017, 9 April 2017 and 15 April 2017; accepted 12 May 2017

\begin{abstract}
This study examined the drivers of housing development in Ebele community area of Benin City, Nigeria. It inquired into the housing finance structures and evaluated factors influencing housing development and infrastructural needs in the rural housing sector. The paper sampled 30 residents from each of the five villages in the study area. Using frequency counts and mean values, the result revealed a considerable gap on the level of satisfaction of the existing housing system. The challenges faced by the rural dwellers were majorly infrastructural deficits and shortage of capital for housing provision since innovative housing finance strategies were lacking. Cultural, ethnic, neighbourhood and infrastructural factors were the most important factors influencing the rural dwellers' housing choice. The study concluded that the cultural values of the people such as kinship and social relations were leading predictors of housing development in Edo state while religion is of secondary importance and therefore recommended their inclusion in any integrated approach to rural housing development.
\end{abstract}

Keywords: Housing, Housing development, Housing financing, Rural, Rural housing.

\section{Background of Study}

The housing sector is a significant contributor to the economy of advanced countries. In developed nations like the United States of America and Canada, this sector is responsible for $10 \%$ to $20 \%$ of the Gross Domestic Product (Deitz, 2015 and Ferreras, 2016). Investment in housing accounts for $15 \%$ to $35 \%$ of aggregate investment worldwide and approximately $10 \%$ of labour force worldwide is employed by this sector (Kolawole, 2015). It is generally accepted that the standard of housing in a nation is an indicator of its extent of economic development standard of living and its height of civilization. The housing sector thus has the potential to generate employment, increase productivity, raise standard of living and alleviate poverty. It also has the capacity to reduce crime rate, insurrections, militancy, and terrorism and substantially address wealth distribution as well as security concerns (Thwala, 2005; Wardrip et al, 2011). It is able to achieve this because investment in housing affects all facets of life through its multiplier effect on economic development. This includes forward linkages to the financial markets and backward linkages to land, building materials, tools, furniture and labour markets (Shuaibu, 2016).

Despite the potency of boosting national development through housing, the Nigerian housing sector has suffered setbacks in various facets and at several stages. According to Okonjo-Iweala (2014) "the housing and construction sector in Nigeria accounts for only about 3 percent of the country's rebased GDP". The country has an extremely low ratio of credit to GDP, and of the little credit provided by banks, only a fraction of it is for mortgages. Despite the size of the nation's economy, mortgage debt to GDP is only about 0.5 percent".

There are lots of housing problems in Nigeria, both in rural areas and urban centres. According to Ibimilua and Ibitoye (2015), the problems in rural areas are centred on qualitative housing (these include problems relating to the physical appearance of the buildings, facilities provided, quality of wall used in the building construction, eminence of the roofing materials, condition of other structural components of the house, and the environmental condition of the house) while that in urban

\footnotetext{
${ }^{1}$ Corresponding Author. Tel: +234 7030060097

Email address: tundeoladokun@yahoo.com

${ }^{2}$ Email address: markson.komolafe@uniben.edu
} 
areas are quantitative (i.e. inadequate supply of housing, leading to further problem such as squatter settlements, overcrowding and pressure on infrastructure) in nature. According to Wahab (1993), rural housing is incomplete due to inadequate social services. It was further submitted that the social services required for rural housing include electricity, water supply, as well as transportation facilities. On the other hand, urban housing problems include homelessness slum dwelling, squatting and overcrowding.

There is need to particularly focus on the development of housing in the rural areas because a considerable proportion of Nigerians live in the rural areas (Toyobo et al, 2014). According to Okoye (1992) the relationship between the urban and rural areas are symbiotic and if any development strategy must be successful, it must recognize that the phenomenon of rural - urban dichotomy in the national landscape is unacceptable and connotes underdevelopment. Moreover, many of the problems of the urban areas can be traced to shortcomings in the rural areas. The mass exodus into the towns is worrisome. The high costs of urban housing and services, the health hazards of shanty towns, the security and political threat posed by the urban unemployed and the adverse economic implications of rural depopulation these are all challenges which result from the influx into towns and cities (Omonigho, 2013). Major Nigerian cities grow at annual rates of $5-17.5 \%$ and suffer from severe pressures on available resources, such as housing, thereby worsening already bad situations in urban employment, management, service delivery and liveability (Akpomuvie, 2010). Also the wide gap in the development levels between the urban and rural areas in Nigeria seems to be threatening the political and social stability of the country. For example, the massive drift into urban areas and the so called "Big cities" due to low level of development in rural areas is one the basic factors responsible for the sharp reduction in agricultural activities and consequent overreliance on the oil sector in Nigeria. This in turn has resulted in a less stable and less diversified Nigerian economy, springing up several political and social consequences like poverty, crime, employment, etc. (Iwayemi, 2006) Nigerian cities such as Lagos, Port-Harcourt, Kano, Onitsha among others where most immigrants settle are characterized by human traffic, vehicular congestions, environmental pollution, consistent in-migration and spurious expansion of territories to accommodate human additions (Aworemi et al. 2011).. Despite having a considerable proportion of the national population, the rural areas are characterized by pervasive and endemic poverty, manifested by widespread hunger, malnutrition, poor health, inadequate access to formal education, deplorable housing state and various forms of social and political menace. Most of these challenges are not as severe in urban areas when compared to the rural areas. (Akpomuvie, 2010). One way of plummeting these is the improvement in rural housing and rural housing conditions in general. It is being recognized that the problems of our urban centres cannot be solved unless those of the rural areas are solved, or at least contained. A relevant way to tackle the unequal level of development between the two areas is addressing the housing problems in the rural areas. This will enable other developmental activities to spring up. In addition, Gyuse (2009) stated that rural housing serves as an abode or place of habitation as it accommodates most rural smallscale industries like pottery, dyeing, among others. It stimulates employment in the rural areas (Popoola, 1988). Its ability to serve as a place for storage, keeping domesticated animals and foster cohesive sense of belonging among rural dwellers by African countries such as found in the rural areas of Edo State, is noteworthy.

Edo state is one of the states that contribute significantly to GDP in Nigeria. The state currently has the fifth highest internally generated revenue in Nigeria (Vanguard, 2016) and is currently Nigeria's second largest producer of rubber and oil palm (World Bank, 2015). Agriculture is the mainstay of the Edo economy and a large proportion of the state citizens depend on agricultural activities for their income. Included among the crops cultivated in the state are oil palm, rubber, cassava, rice, plantain, yam, sweet potatoes, sugar cane, cashew, groundnuts, tomatoes, cotton, and tobacco. A number of agro-processing businesses in the oil palm and rubber processing industry like Okomu Oil Palm Plc and Presco Nigeria Plc and several agricultural research institutes such as the Nigerian Institute for Oil palm Research (NIFOR) and the Rubber Research Institute of Nigeria (RRIN) are located in the state (World Bank, 2015). Based on its abundant land and water resources, Edo has a great potential to expand agriculture activities and thus improve livelihoods in the state. However, as it applies in most other states in Nigeria, the deplorable state of the rural life, especially the rural housing and resultant migration to urban areas create doubts on the possibility of achieving this since the seat of primary production activities lies in the rural areas.

In order to address the problems in the rural housing in Nigeria, it is pertinent to examine the factors/ forces that influence the development of rural housing. Sustainable housing provision requires proper definition of housing needs, and the participation of the end users to ensure their satisfaction. Without reference to the perceptions and values of the people, most housing programmes often fail. This is because the inhabitants are in the best position to identify their needs, and order their priorities (Ayoola and Amole, 2014). Attitudes towards space, use and organization of space, are all linked to certain factors which are often best understood by the inhabitants themselves. Local settlements have vast understanding of their environment, their local building resources and the ways of making the best uses of them. Thus housing that will be acceptable by the local settlements must have put into consideration the cultural, climatic, and socio-economic circumstances of the people. At the level of planning and decision-making, local participation is indispensable to sustainable housing. In the light of this background, this study intends to investigate the drivers of rural housing development in Edo state, Nigeria taking the end users as the study focus. This is with a view to providing information relevant to arriving at well-targeted policies that will help the government and other stakeholders in effective and efficient prioritization of rural housing development efforts. Literature as regards rural housing in Nigeria has been dominated by housing conditions and implications 
on rural health life, evaluation of rural housing problems, relevance of infrastructural facilitates to rural housing development, micro and mortgage financing of rural housing and housing qualities in the rural areas $(\mathrm{Ogu}$, 1994; Toyobo et al, 2014; Ijaiya et al., 2014; Olawepo, 2009; Ogundahunsi and Adejuwon 2014). Literature on the factors influencing rural housing development in Nigeria, despite its importance, is sparse in literature, thus this study comes in to bridge this gap. The study focuses on Edo state due to its rich agricultural and other resources base and the potential contributions these can make to improved livelihood in Nigeria if the rural housing challenges are tackled.

\section{Literature Review}

Housing, in general, is the process of providing a residential environment made up of shelter, infrastructure and services; to others, it extends beyond this as it represents one of most recognised pointers to a person's standard of living and recognition in the society (Nubi, 2008). Housing in this perspective extends beyond the physical structures to the neighbourhood and infrastructure. Turner (1972) added that it involves land, labour and finance acquisition processes. The housing system determines the full range of inter-relationships between all of the actors (individual and corporate), housing units and institutions involved in the production, consumption and regulation of housing (Bourne, 2007). It encompasses interactions among the organization of the housing market (the institutional structure), the actors (supply \& demand), and housing policy, particularly the economic, demographic, political and spatial factors which influence these (Van der Heijden, 2013). An inclusive housing system stimulates adequate housing production, helps produce a mix of housing choice (tenure, location, and quality) and assist those who cannot afford adequate and appropriate housing (Van der Heijden, op cit.). Efficient housing provision is therefore hinged on an inclusive, active and effective housing system.

There are several factors which determine/influence the provision/ development of housing. Aribigbola (2008) pointed out availability of income and stability and effectiveness of existing policies, regulations and practices. Many a times, the low income earners attract less attention by investors hence, majority of the rural dwellers, most of who fall in this category suffer as housing providers pay less attention to their needs.

According to Olotuah (2009) socio-economic circumstances, cultural background, world views, and the political and economic situation of the country are determinants of users' housing needs. In order to capture the needs of the rural populace in housing policies, an indepth understanding of housing values of the prospective beneficiaries of the policies must be taken into cognisance by the policy makers. Beamish (1989) describes housing values as the preferences and choices that people consider in housing selection. This is in line with Roske (1983)'s definition: "the underlying criteria for choice in housing and other aspects of life". Beyer (1959) came up with four hierarchy of values: economy, family (physical, mental health and family centrism), personal (aesthetics, leisure and equality) and social storage.

Economy- those falling in this category pay more attention to how much they can make economic use of goods and services. Their choices are based on the selling price and good value for money or sound business judgement. Family- factors that foster good family relationships and unity within the family and how they influence the physical and mental well-being of family members are prioritized by this cluster. Personal- those in this category are individualistic and desire independence and self-expression. They take personal view of their physical and social environment. Social-families in this category view housing in terms of its effect on their social status. This cluster is considered upwardly mobile. Deeply subsumed in the social criteria for housing selection are the cultural and ethnic values (Olayiwola et al, 2006; Makinde, 2015). Spencer-Oatey (2008) describes culture a set of basic assumptions and values, orientations to life, beliefs, policies, procedures and behavioral conventions that are shared by a group of people, and that influence (but do not determine) each member's behavior and his/her interpretations of the 'meaning' of other people's behavior. Ethnicity is a term that is used to refer to a wide variety of groups who might share a language, historical origins, religion, identification with a common nation-state, or cultural system (Spencer-Oatey, 2012). The nature of the relationship of a group's ethnicity to its culture will vary greatly depending on a number of other important characteristics. For example, the sharing of cultural traditions and customs, community institutions and establishments, and similar labor market experiences may all act to facilitate the concentration of the members of an ethnic group (Makinde, 2015). Culture, ethnicity, race, nationality and similar other phenomenon are collectively referred to in literature as "Sociocultural factors" (Morris and Winter, 1978; Chiu, 2002; Jiboye, 2004) The satisfaction derived by the inhabitants of a particular housing unit is a reflection of the degree to which they feel in conformity with their socio-cultural background (Jiboye 2008). According to Olayiwola et al, (2006), "If the essence of a house is to be fully appreciated within the context of human habitation, then the need for the preservation and promotion of socio-cultural values through housing design and forms should not be predicated on emotional and overzealous rhetoric, but on the relationship between housing and cultural structures".Lin Shi (2005) also corroborates Beyer (1959)'s hierarchy of value that most households hold hierarchy of values as against just one value. Even within a household, individual members hold different forms of housing values. According to Lindamood \& Hanna (1979), households' housing decisions are arrived at by trading off different housing values within the family. Abraham Maslow's hierarchy of needs recognised the unlimited nature and insatiability of human wants. When one is satisfied, another need emerges (Maslow, 1954). Thus a complete satisfaction is impossible. In such situation, the more important values have to be met one after the other and certain trade- offs will be made.

In Abdul (2008), Adeniyi (2007), Bourne (2007) and Chatterjee (2008), availability of finance is noted as a 
primary determinant of housing development. Adamu (2007) asserts that housing provision is hinged on effectiveness in land administration. Egunjobi, (2007) makes reference to availability of loan or other form of assistance for building.

Aribigbola (2011) identified the pointers of sustainability in housing provision as housing quality, affordability and social equity and justice in terms of accessibility. In order to achieve sustainability in housing provision there is need for major changes in the society, institutions need to be restructured and management approaches fine-tuned. It requires the appropriate political will based on the conviction of the responsibility of government to its citizens, and the need to create humane and decent environment for dignified living. According to Olotuah and Bobadoye (2009), adequate priority should be given to the housing needs of the population, coupled with a well worked out and coordinated programme to achieve this, if sustainable housing must be realised. Sustainable housing provision is thus subject to such underlying factors as decision making, policy formulation, policy execution and monitoring, social acceptability and economic feasibility. These factors must take into cognizance the bottom-up participatory approach in housing provision involving genuine local participation by people at the grassroots level.

Bello and Olatubara (2014) noted that the social, cultural, environmental, and economic facets of housing should be addressed in an integrated fashion. For example, affordable housing should not be considered only on cost basis; environmental and social issues (including people preferences, lifestyles, and cultural aspirations), as well as economic impacts should not be addressed separately nor ignored. According to the authors, accumulation of vulnerabilities and precarious housing situations results when any dimension of sustainability is ignored. Planning and building housing within an integrated sustainability framework makes it more accessible to low-income rural households and responds to their diverse social and cultural needs. This will have multiple positive outcomes for people's physical and mental health and safety, for economy, and for the built and natural environments. Besides, sustainable houses hold up for a longer time, making them a smart investment for government and other stakeholders.

Several studies have been conducted to inquire into the factors influencing housing development/ housing provision, especially in the rural areas, being the focus of this study. Some of these include Shui et al (2014) which examined the influencing factors on resettled farmer's satisfaction and occupancy under the policy of "the balance between urban construction land increasing and rural construction land decreasing" in Chengdu City, China. The result of the logistic regression carried out revealed that the positive factors that contribute to the famer's satisfaction, include land-rights guarantees, compensation for land consolidation, sewage treatment and the living environment. In contrast, public facilities, commercial service networks and resettled area's maintenance are negative factors for farmer's satisfaction. This study focused majorly on resettled farmers and evaluations were based on a particular rural housing policy. The result therefrom can thus not be generalized on other rural housing planning efforts, especially those not targeted at a particular group.

Essendi and Madise (2014) examined the relationships between perception of development and observed socioeconomic, demographic and wellbeing variables in rural Kenya. Using structural equation modeling techniques to analyze data collected from 275 individuals, selected at the individual and household levels, significant relationships were found between perception of development and gender, age, perceived household wellbeing and health risk factors (alcohol use and cigarette smoking). This study concluded that even within the same community, people's perceptions will vary depending on their age, gender, perceived household wellbeing and health risk factors including alcohol use and having ever smoked tobacco products. The study however did not consider other external factors like government legislations, infrastructure etc. and their impact on actual or perceived rural housing development.

Beer and Tually (2012) examined the drivers that influence the characteristics and operation of housing markets and housing affordability in rural and regional areas of Australia. Fifteen case study locations were chosen across a range of regional areas, spanning nonmetropolitan population centers through to rural and remote regions. Drawing on ABS Census data and house and unit price data, the study revealed that private rental supply in particular has been under-developed. This is due to a shortage of investors, inappropriate planning regulations and, in some cases, the low wage and high variability labour markets in these regions which do not offer sufficient comfort for investors. Also lack of economies of scale in rural and remote Australia is considered to be a barrier to housing supply. The study, though similar in focus, is however based on a more developed economy which differ in characteristics from an emerging economy like Nigeria.

Jamini et al (2014) reviewed and assessed the factors influencing villagers' level of satisfaction with rural housing in Kermanshah Province, Iran. Using descriptive and analytical survey on rural households selected in four Avramanat Township located in Kermanshah province, it was discovered that the satisfaction level of the rural residents was less than average. In general economic and health factors proved to be the most important factors influencing satisfaction levels in the four areas surveyed. As observed on other existing studies, only a few factors were examined in this study. There are several other factors which define the nature of development in rural housing. This study intends to cover some of these factors.

Ebadi et al (2015) examined the functional changes of the rural settlements of Southwestern Tehran in the PostIslamic revolution in Iran (1978-2014). Three hundred and seventy four (374) heads of households were sampled on 13 villages and four rural districts using cluster sampling. The results indicated that villages in the Southwest of Tehran during the revolution years were involved mostly in primary functions such as agriculture, animal husbandry and horticulture while the industry and services in rural areas were at the lowest level. The presence of industries, factories and workshops in agricultural lands surrounding villages, low prices of 
agricultural lands and the expansion of communication networks have extended various functions including industrial and service functions. The evaluation is time specific and the study was particularly tailored at measuring the impact of the post Islamic revolution.

The study of Jabareen (2005) examined the relationship between culture and housing preferences in Gaza, Palestinian. Relying on Amos Rapoport's framework, the author segregated "culture" into different components of gender-to-face, politics, religion, kinship, and social relations to predict housing preferences in Gaza City. The result of the face-to-face interview revealed that among cultural components, kinship relations and attitudes toward women are likely to be crucial for individual Palestinians seeking new housing.

In the Nigerian property market, Olotua and Babadoye (2009) reviewed the intervention of the public sector in housing in Nigeria and critically examines the impact on the general populace, especially the urban poor. The study discovered that the involvement of the public sector in housing in Nigeria has been more of policy formulation than housing delivery. It asserts that the bottom-up approach, involving the direct participation of the local communities is vital in ensuring sustainability in housing provision. The study is not only targeted majorly at the urban poor, it also focuses mainly on the intervention of the public sector.

Aribigbola (2008) examined the suitability and potential of the policies to addressing housing affordability and shortages as well as the impact of the policy on housing delivery in Akure, Ondo State, Nigeria as a case study. Using structured questionnaire administered on selected residents of the city, the study revealed that the policy has not made much contribution to housing provision. The paper argues that although the policy poses great potentials to improving housing delivery, there is a need to rethink and repackage the policy so that majority can benefit from it. The study also stressed the need to incorporate social housing into the policy to assist the very poor that cannot take care of their housing consumption needs. The study concluded that the approach of leaving housing provision to the vagaries of market forces would not be expected to provide affordable housing especially to the poor. It is also apparent from this study that the focus is on evaluation of existing housing policies and the study area is urban. Inquiry into the factors that will influence rural housing is not directly addressed in this study.

Toyobo et al (2011) assessed the relevance of infrastructural facilities to rural housing development as it is applied to Lagelu local government in Oyo State, Nigeria. The study identified the various rural development programmes embarked upon by the local government, examined the socio economic importance of rural development projects executed by the Lagelu local government and assessed the existing infrastructural facilities in the area. Using descriptive statistical techniques, the findings reveal inadequacy of infrastructural facilities, absence of economic empowerment programme and poor housing quality. The study recommended that appropriate sustainable measures be put forward in order to improve the infrastructural facilities coupled with relevant programmes of reducing poverty in Lagelu local government area. Also, as observed on other studies, this study is evaluative and assessed existing rural development programmes and infrastructural base in the study area.

The above studies and several other existing studies have focused less on the choices and preferences of the rural dwellers in housing development and inquiry into the factors influencing rural housing development based on users' assessment is sparse despite the importance to effective housing provision, especially in the rural areas. This study therefore fills the existing gap in literature, first by evaluating the existing housing system, based on assessment of the rural inhabitants' challenges and level of satisfaction and second, by inquiring into the factors that will influence development in the rural housing, taking into cognizance, the choices and preferences of the rural dwellers in Ebele community, Edo state, Nigeria.

\section{Data and Methodology}

The study was carried out in Ebele community of Edo State, Nigeria. Ebele village is situated in Igueben Local government of Edo state. Its geographical coordinates are $6^{\circ} 30^{\prime} 0$ " North and $6^{\circ} 13^{\prime} 0$ " East. Ebele is surrounded by communities such as Amahor, Ekpon, Ewohinmi, Ewossa, Idunmuodi, Izogen, Ogwa. The communities that make up Ebele are Eguare, Ologhe, Okuta, Idumowu and Okpujie.

The economic mainstay of Ebele include commerce, cottage industry (cloth weaving, basket making, etc.), agriculture, furniture making, wood, etc. In addition, Ebele is also reputed for palm wine tapping and oil palm production. Ebele is one of the major traditional towns in Esan, linking to the Benin kingdom, otherwise known as the Binis like most other Esan communities that are involved in the cottage industry. The population of Ebele appears to be controversial or unknown, however, Igueben Local government of which Ebele is a major constituent part has a population of 69639 according to 2006 population census.

Ebele as a local community has relied on local processing of its agricultural products. Thus, from production to processing to distribution, the economy still relies on manual inputs and implements not sufficient to transform the economic base from subsistence to commercial. Thus, with support, Ebele stand the chance of an industrial revolution in which palm wine, palm oil and industrialization in general can experience a transformation. With its vast land suitable for agriculture, industrial agricultural inputs remain the viable instrument of economic turnaround for the people. This initiative is very likely to spread to the communities contiguous to it showing that the central position that Ebele occupies in the community would not only affect Ebele but its surroundings and neighborhood communities as well.

In recent times, there has been a drift of population, especially the youths, from Ebele community and other villages in the local government into surrounding urban areas in the State in search for employment opportunities and better living conditions. There is therefore particular need to examine the factors that will keep the inhabitants 
in the village to enable them explore the opportunities in the rural life. Given the contribution of housing to rural living conditions, inquiry into the factors influencing the rural housing development is pertinent.

For this study, data were collected from the five communities that make up Ebele village. Thirty (30) respondents were selected purposively from each of the five communities, adding up to 150 questionnaire distributed in all. Selection was done to ensure spread across geographical space, living standard, family size, and age groups. Out of the 150 questionnaire distributed, 106 were retrieved. The questionnaire detailed the personal characteristics of the respondents and information relating to the existing housing structure, its performance and the respondents' preference on housing choice in the area.

The data were analysed using frequency counts and mean. Frequency counts were mainly used in analysing information related to the personal characteristics of the respondents and the dwelling units they occupy while mean value was used in analysing those related to the level of satisfaction on the existing housing system, challenges on existing housing structure, housing finance choices, factors influencing the housing development and the infrastructural needs in the housing sector.

The mean values were figured out from the respondents' ratings of the parameters used in measuring the housing characteristics and preferences. The ratings were in five scales (5, representing the highest scale and 1 , the least). From the ratings, the mean values for each of the parameters were calculated by multiplying the total frequency of response on each scale with the weight attached. The resultant figures gotten from each scale were added up and divided by the total response on each of the parameters. This is further presented in equation 1 below.

Mean Value $=\frac{\sum_{1}^{5} R \times W}{T}$

Where:

$R=$ total number of responses on a particular scale on each parameter

$W=$ Weight attached to each scale (ranging from 1 to 5)

$T=$ Total number of responses on all scales for each parameter

The resultant mean values were then used to rank the parameters where appropriate. The section below details the result of the analysis.

\section{Result and Implications}

This section is divided into five subsections. The first, reporting the general characteristics of the participant and the dwelling units they occupy. Following this is a general assessment of the existing housing system in the study area. Thereafter, information regarding the housing finance structure of the area is presented. Data on the motivations behind the occupants' housing choices in the area is presented next and the section concludes with implications of the results and conclusions.

\subsection{General Characteristics of Participants}

Table 1 presents the general characteristics of the participants in the survey. From Table 1, it is evident that the participants are spread across the various adult age categories with majority, between ages $40-60$ years. There were no single respondents and majority of the respondents have spent at least 30 years in the locality. Only a few studied beyond secondary school level, 58.5\% of the participants do not earn more than N20,000 per month and majority's occupation is farming. Household sizes of the respondents range from 1 to 10 and the modal mode of ownership is self-ownership. This result reveals that the respondents consists majorly of low income middle aged and older adults, majority of whom are illiterate and whose major occupation is farming. From the result, it is also apparent that the respondents have lived in the community a period of time to be able to give relevant information on the housing systems.

Table 1: General characteristics of participants and housing units

\begin{tabular}{|c|c|c|}
\hline Category & Frequency & $\%$ \\
\hline \multicolumn{3}{|l|}{ Age } \\
\hline $31-40$ & 12 & 11.3 \\
\hline $41-50$ & 42 & 39.6 \\
\hline $51-60$ & 40 & 37.7 \\
\hline $61-70$ & 12 & 11.3 \\
\hline \multicolumn{3}{|l|}{ Marital status } \\
\hline Married & 90 & 84.9 \\
\hline Widowed & 16 & 15.1 \\
\hline \multicolumn{3}{|l|}{ Number of Years Spent in the Locality } \\
\hline $1-10$ & 4 & 3.8 \\
\hline $11-20$ & 17 & 16 \\
\hline $21-30$ & 8 & 7.6 \\
\hline $31-40$ & 18 & 16.9 \\
\hline $41-50$ & 23 & 21.7 \\
\hline $51-60$ & 28 & 26.4 \\
\hline $61-70$ & 8 & 7.6 \\
\hline \multicolumn{3}{|l|}{ Level of Education } \\
\hline No Formal Education & 12 & 11.3 \\
\hline Primary Education & 36 & 34.0 \\
\hline Junior Secondary School Certificate & 11 & 10.4 \\
\hline Senior Secondary School Certificate & 26 & 24.5 \\
\hline Adult Education & 4 & 3.8 \\
\hline HND/BSC & 17 & 16.0 \\
\hline \multicolumn{3}{|l|}{ Monthly Income in Naira } \\
\hline $1000-10,000$ & 9 & 8.5 \\
\hline $11000-20,000$ & 53 & 50.0 \\
\hline $21,000-30,000$ & 5 & 4.7 \\
\hline $31,000-40,000$ & 16 & 15.1 \\
\hline $41,000-50,000$ & 6 & 5.7 \\
\hline $51,000-60,000$ & 8 & 7.5 \\
\hline $61,000-70,000$ & 9 & 8.5 \\
\hline \multicolumn{3}{|l|}{ Major Occupation } \\
\hline Farming & 72 & 67.9 \\
\hline Trading & 8 & 7.5 \\
\hline Artisan & 4 & 3.8 \\
\hline Farm Produce Processing & 4 & 3.8 \\
\hline Others & 18 & 17.0 \\
\hline \multicolumn{3}{|l|}{ Household Size } \\
\hline $1-5$ & 54 & 50.9 \\
\hline $6-10$ & 52 & 49.1 \\
\hline
\end{tabular}




\begin{tabular}{llc}
\hline Mode of Ownership & & \\
Self-Owned & 36 & 34 \\
Inherited & 15 & 14.2 \\
Rented & 29 & 27.4 \\
Family House & 26 & 24.5 \\
Total & 106 & 100 \\
\hline
\end{tabular}

\subsection{Level of satisfaction on the existing housing} system

Before examining the factors influencing housing development in the area, the occupants' level of satisfaction was sought first, to be able to detect the gaps to be filled on housing in the area. From Table 2 below, the mean value observed on the level of satisfaction is 3.30. This indicates an average level of satisfaction. Twenty eight (26.4\%) expressed total dissatisfaction on the existing housing situation in the study area. This result reveals that a lot of gap can still be filled to optimise the existing level of satisfaction on the housing situation. To prevent further emigration in this area, there is therefore need to improve on the housing condition through strategies tailored especially to the housing preferences of the rural dwellers. In order to further explain the occupants' level of satisfaction, the respondents were asked to indicate and rate (on a five point scale: very severe -5 , to not severe-1) the housing challenges they are facing. The housing challenges limiting the occupants' level of satisfaction is as presented in Table 3. The following challenges (in rank order) have been ranked relatively higher: "inadequate infrastructure", "inadequate capital" and "high building cost". High building cost is traceable to poor infrastructure system which accentuates difficulties in transporting building materials. Challenges relating to housing structure, legislative system and public housing are less pronounced in the area. Since only $27.4 \%$ of the respondents occupy rented apartments, provision of public housing is less popular as an alternative housing option in the area as most inhabitants occupy self-owned or family houses. From this result, it is apparent that the more pressing challenges centre on infrastructure and availability of fund for housing development. This result is in tandem with African Monitor (2012)'s assertion that inadequate and unreliable infrastructure services are common in the majority of rural communities in Africa. According to Adebayo (2014) the issue of funding is a big challenge on rural housing and other rural development programmes in Nigeria. Sustainable housing should therefore focus on issues relating to affordability and improvement in housing quality through better infrastructure. These housing challenges recorded are peculiar to rural areas (Wahab, 1993; Ibimilua and Ibitoye, 2015) and are traceable to weak rural development structure and less concentration of development effort on rural areas relative to urban areas.

Table 2: Respondents' rating of satisfaction on existing housing system

\begin{tabular}{lcccccccc}
\hline & $\begin{array}{c}\text { Very } \\
\text { Satisfactory }\end{array}$ & $\begin{array}{c}\text { Moderately } \\
\text { Satisfactory }\end{array}$ & $\begin{array}{c}\text { Slightly } \\
\text { Satisfactory }\end{array}$ & Indifferent & $\begin{array}{c}\text { Not } \\
\text { Satisfactory }\end{array}$ & Mean & S.D. & Total \\
\hline Frequency & 4 & 33 & 24 & 17 & 28 & 3.30 & 1.266 & 106 \\
Percentage & $3.8 \%$ & $31.1 \%$ & $22.6 \%$ & $16.0 \%$ & $26.4 \%$ & & & $100.0 \%$ \\
\hline
\end{tabular}

Table 3: Challenges on existing housing system

\begin{tabular}{|c|c|c|c|c|c|c|c|c|}
\hline & \multirow{4}{*}{ Mean } & \multirow{4}{*}{$\begin{array}{c}\text { Std. } \\
\text { Deviation }\end{array}$} & \multirow{4}{*}{$\begin{array}{l}\text { Std. } \\
\text { Error }\end{array}$} & \multicolumn{2}{|c|}{$95 \%$ Confidence } & \multirow{4}{*}{ Min } & \multirow{4}{*}{ Max } & \multirow{4}{*}{ Rank } \\
\hline & & & & \multicolumn{2}{|c|}{ Interval for Mean } & & & \\
\hline & & & & Lower & Upper & & & \\
\hline & & & & Bound & Bound & & & \\
\hline Inadequate infrastructure & 4.54 & 0.692 & 0.067 & 4.4 & 4.67 & 3 & 5 & 1 \\
\hline Inadequate capital to build & 4.43 & 0.895 & 0.087 & 4.26 & 4.61 & 2 & 5 & 2 \\
\hline High building cost & 4.19 & 1.374 & 0.133 & 3.92 & 4.45 & 1 & 5 & 4 \\
\hline Unavailability of building materials in the locality & 4.14 & 0.81 & 0.079 & 3.99 & 4.3 & 2 & 5 & 5 \\
\hline Difficulty in accessing land for building & 3.76 & 1.262 & 0.123 & 3.52 & 4.01 & 1 & 5 & 6 \\
\hline Inadequate expertise to handle desired building style & 3.25 & 1.194 & 0.116 & 3.02 & 3.48 & 1 & 5 & 7 \\
\hline Unaffordable housing structure & 3.21 & 1.426 & 0.138 & 2.93 & 3.48 & 1 & 5 & 8 \\
\hline $\begin{array}{l}\text { Complicated legislative system which inhibits } \\
\text { flexibility }\end{array}$ & 3.13 & 1.219 & 0.118 & 2.9 & 3.37 & 1 & 5 & 9 \\
\hline Inaccessible public housing structure & 3.12 & 1.35 & 0.131 & 2.91 & 3.34 & 1 & 5 & 10 \\
\hline
\end{tabular}

Since shortage of capital for housing development is a major challenge to housing in the locality, inquiry into the existing housing finance options in the area is pertinent to solving housing challenges related to housing finance. In order to achieve this, a pilot study was carried out to identify the existing housing finance structure in the area. The result reveals only four major sources. These include personal savings, borrowing from cooperative societies, support from relatives and borrowing from banks. Table
4 below presents the result on extent of use of the alternative housing finance sources in the area. It can be seen from the table that personal savings is the most frequently used, followed by borrowings from cooperative societies and support from relatives. Only a few of the inhabitants borrow from the banks to execute housing projects. This is traceable to the low cost housing being adopted predominantly in the area adopted in the locality and possibly, paucity of other alternative housing 
finance options in the locality. This result is in line with Akeju (2007)'s submission that Nigeria is yet to develop a vibrant mortgage market and houses continue to be provided through the tortuous traditional method of buying land and building over some years, which could be an individual's entire life time.To improve on existing housing finance structure, there is need for introduction of better housing finance alternatives, coupled with effective awareness strategy to sensitise the inhabitants on impact on improved housing systems. .

Table 4: Extent of use of alternative housing finance sources in the locality

\begin{tabular}{|c|c|c|c|c|c|c|c|c|c|}
\hline & \multirow{2}{*}{$\mathrm{N}$} & \multirow{2}{*}{ Mean } & \multirow{2}{*}{$\begin{array}{c}\text { Std. } \\
\text { Deviation }\end{array}$} & \multirow{2}{*}{$\begin{array}{l}\text { Std. } \\
\text { Error }\end{array}$} & \multicolumn{2}{|c|}{$\begin{array}{l}95 \% \text { Confidence } \\
\text { Interval for Mean }\end{array}$} & \multirow{2}{*}{\multicolumn{2}{|c|}{ Minimum Maximum }} & \multirow{2}{*}{ Rank } \\
\hline & & & & & $\begin{array}{l}\text { Lower } \\
\text { Bound }\end{array}$ & $\begin{array}{l}\text { Upper } \\
\text { Bound }\end{array}$ & & & \\
\hline Personal savings & 106 & 4.64 & .928 & .090 & 4.46 & 4.82 & 1 & 5 & 1 \\
\hline Cooperative/meeting borrowings & 106 & 3.47 & 1.007 & .098 & 3.28 & 3.67 & 1 & 5 & 2 \\
\hline Support from relatives & 106 & 3.23 & 1.132 & .110 & 3.01 & 3.44 & 1 & 5 & 3 \\
\hline Loan from banks & 106 & 1.63 & .735 & .071 & 1.49 & 1.77 & 1 & 4 & 4 \\
\hline
\end{tabular}

The respondents were asked the factors that will influence housing development in the locality. Table 5 below presents the result of the survey. The result is that cultural and ethnic reasons were perceived most important factors influencing housing development in the area. Other factors that also ranked high include "proximity to place of work", "Proximity to friends and families", "Environmental friendliness of the area", "Accessibility and affordability of the land" and "Availability of better infrastructure". The result reveals that the respondents place high value on socio cultural values even above neighborhood and infrastructural factors. This finding is in consonance with Axton (2013) and Bello and Olatubara (2014) that culture influences housing choices and behaviors. According to FAO (n.d), most rural societies are relatively 'integrated', in the sense that the various components of life (e.g. agricultural and non-agricultural, 'economic', 'social' end 'political', religious and secular) are closely interrelated. Rural people do not easily recognize the distinctions which planners, extension workers and other government officials make between,

Table 5: Factors influencing housing development in the locality for example, the responsibilities of different agencies or 'economic' and 'social' planning, because in their own lives all these things affect each other. In line with the findings in Jabareen (2005), cultural values such as kingship and social relations were leading predictors of housing development in Edo state followed closely by religious consideration. Thus, an integrated approach to planning that will meet the yearnings of rural dwellers must not only be limited to the planning point of view (e.g. the 'agricultural' or the 'economic') but take account of other related aspects of kingship, social relations and religion. The implication of this is that whatever form housing development initiatives may take, adequate cognizance must be taken to ensure that the people get satisfaction on matters that border on their culture and ethnicity. Some neighborhood factors, infrastructural and security factors are also deemed to be of priority. Factors deemed less important include "Proximity to recreational activities", "Quietness and serenity of the environment" and "Religious reasons" in rank order.

\begin{tabular}{|c|c|c|c|c|c|c|c|}
\hline & \multirow{2}{*}{ Mean } & \multirow{2}{*}{$\begin{array}{c}\text { Std. } \\
\text { Deviation }\end{array}$} & \multirow{2}{*}{$\begin{array}{l}\text { Std. } \\
\text { Error }\end{array}$} & \multicolumn{2}{|c|}{$\begin{array}{l}\text { 95\% Confidence } \\
\text { Interval for Mean }\end{array}$} & \multirow{2}{*}{ Min } & \multirow{2}{*}{ Max } \\
\hline & & & & $\begin{array}{l}\text { Lower } \\
\text { Bound }\end{array}$ & $\begin{array}{l}\text { Upper } \\
\text { Bound }\end{array}$ & & \\
\hline Cultural reasons & 4.35 & 0.479 & 0.047 & 4.26 & 4.44 & 4 & 5 \\
\hline Ethnic reasons & 4.18 & 0.629 & 0.061 & 4.06 & 4.3 & 3 & 5 \\
\hline Proximity to place of work & 4.08 & 1.066 & 0.104 & 3.87 & 4.28 & 2 & 5 \\
\hline Proximity to friends and families & 4.08 & 0.782 & 0.076 & 3.93 & 4.24 & 3 & 5 \\
\hline Environmental friendliness of the area & 4.07 & 0.876 & 0.085 & 3.9 & 4.23 & 2 & 5 \\
\hline Accessibility and affordability of the land & 4.04 & 0.816 & 0.079 & 3.88 & 4.19 & 2 & 5 \\
\hline Availability of better infrastructure & 4.04 & 0.755 & 0.073 & 3.89 & 4.18 & 3 & 5 \\
\hline Security reasons & 3.81 & 1.061 & 0.103 & 3.61 & 4.02 & 2 & 5 \\
\hline Proximity to neighborhood services & 3.44 & 0.874 & 0.085 & 3.28 & 3.61 & 2 & 5 \\
\hline Proximity to market area & 3.16 & 0.852 & 0.083 & 3 & 3.32 & 2 & 5 \\
\hline less stringent government regulatory policies & 2.95 & 1.214 & 0.118 & 2.72 & 3.19 & 1 & 5 \\
\hline Proximity to recreational activities & 2.79 & 1.185 & 0.115 & 2.56 & 3.02 & 1 & 5 \\
\hline Quietness and serenity of the environment & 2.71 & 1.154 & 0.112 & 2.49 & 2.93 & 1 & 5 \\
\hline Religious reasons & 1.85 & 0.871 & 0.085 & & & 1 & 4 \\
\hline
\end{tabular}

In order to further inquire into the occupants' housing choices, the occupants' preference on housing features was also surveyed. Table 6 below presents the result of the survey. From the result, the occupants' preference for 
cultural values also played out as "blend with cultural value" also tops the list (mean value of 3.85 ). This is followed immediately by "bigger housing sizes" and "environmental friendliness of the building systems". The

Table 6: Housing features preferred by occupants in the area result revealed a low preference for small housing units possibly due to a relatively large family size by a considerable proportion of the respondents $(49.1 \%$ have family sizes of more than 5 persons).

\begin{tabular}{|c|c|c|c|c|c|c|c|}
\hline & \multirow{2}{*}{ Mean } & \multirow{2}{*}{$\begin{array}{c}\text { Std. } \\
\text { Deviation }\end{array}$} & \multirow{2}{*}{$\begin{array}{l}\text { Std. } \\
\text { Error }\end{array}$} & \multicolumn{2}{|c|}{$\begin{array}{l}\text { 95\% Confidence } \\
\text { Interval for Mean }\end{array}$} & \multirow{2}{*}{ Min } & \multirow{2}{*}{$\operatorname{Max}$} \\
\hline & & & & $\begin{array}{l}\text { Lower } \\
\text { Bound }\end{array}$ & $\begin{array}{l}\text { Upper } \\
\text { Bound }\end{array}$ & & \\
\hline Blend with cultural value & 3.85 & 0.728 & 0.071 & 3.71 & 3.99 & 2 & 5 \\
\hline Bigger housing sizes & 3.66 & 1.032 & 0.1 & 3.46 & 3.86 & 2 & 5 \\
\hline Environmental friendliness of the building systems & 3.18 & 0.924 & 0.09 & 3.00 & 3.36 & 2 & 5 \\
\hline Better internal facilities/conveniences & 2.56 & 0.967 & 0.094 & 2.37 & 2.74 & 1 & 5 \\
\hline Smaller housing sizes & 2.25 & 0.757 & 0.073 & 2.11 & 2.4 & 1 & 4 \\
\hline
\end{tabular}

Given the fact that infrastructure is recurrent both on existing housing challenges and housing factors preferred by the occupants, further inquiry on occupants' preference regarding infrastructural features is pertinent to tackling housing challenges through this medium.

Table 7: Infrastructural features preferred by occupants in the area

\begin{tabular}{|c|c|c|c|c|c|c|c|}
\hline & \multirow{2}{*}{ Mean } & \multirow{2}{*}{$\begin{array}{c}\text { Std. } \\
\text { Deviation }\end{array}$} & \multirow{2}{*}{$\begin{array}{l}\text { Std. } \\
\text { Error }\end{array}$} & \multicolumn{2}{|c|}{$\begin{array}{l}95 \% \text { Confidence } \\
\text { Interval for Mean }\end{array}$} & \multirow{2}{*}{ Min } & \multirow{2}{*}{$\operatorname{Max}$} \\
\hline & & & & $\begin{array}{l}\text { Lower } \\
\text { Bound }\end{array}$ & $\begin{array}{l}\text { Upper } \\
\text { Bound }\end{array}$ & & \\
\hline Electricity supply & 4.27 & 0.64 & 0.062 & 4.15 & 4.4 & 3 & 5 \\
\hline Educational facilities & 4.25 & 0.741 & 0.072 & 4.1 & 4.39 & 2 & 5 \\
\hline Health facilities & 4.18 & 0.802 & 0.078 & 4.02 & 4.33 & 2 & 5 \\
\hline Transportation facilities & 3.8 & 1.073 & 0.104 & 3.6 & 4.01 & 2 & 5 \\
\hline Recreational facilities & 3.54 & 1.016 & 0.099 & 3.34 & 3.73 & 2 & 5 \\
\hline Healthy water supply & 1.79 & 0.713 & 0.069 & & & 1 & 4 \\
\hline
\end{tabular}

Table 7 presents the result on occupants' preference for infrastructural facilities. The result reveals that electricity supply is foremost of the occupants' infrastructural needs. This is followed by educational facilities, health facilities, transportation facilities and recreational facilities. Healthy water supply is the least needed infrastructure in the area. This is attributable to the fact that the inhabitants are used to the use of wells and boreholes. The fact that the mean value on most features is more than 3.5 validates the need for infrastructural facilities in the area

\section{Conclusion}

The study revealed that ample gaps can be filled on housing development in the rural areas thereby enhancing more balanced development required for sustainable national growth. Existing challenges on rural housing focus on infrastructural and capital shortage. The study also revealed dearth of improved housing finance structure which is partly responsible for the existing rural housing challenges. To improve on the status quo, there is need to step up the existing housing finance structure and strengthen the infrastructural base and social services without playing down on the ethnic and cultural values of the rural life. This will foster the required balance in the rural and urban sectors, thus achieving sustainable national development.
The study had evaluated factors responsible for rural housing development in 5 Villages in Edo state, Nigeria and have established a huge gap in meeting the housing needs of the rural populace. Inspite of the importance of rural areas in enhancing national development, the study found gross dissatisfaction of rural dwellers with the available housing condition. This hangs largely on the inadequacy of infrastructure and high cost of housing development.

In addition, the study found inadequate capital/finance for housing development owing to dependence on personal savings and borrowings from cooperatives societies and family members for finance.

Inspite of this, housing development is driven at rural areas by the need to preserve their cultural beliefs and value which requires indigenes to have a family house built in their place of origin in line with the design and features that are in vogue and in compliance with the acceptable norms of the people of the areas.

A major policy implication is the need for the government to remold the existing housing finance system in line with the cultural beliefs of the rural areas. This should incorporate system that gives them sense of belonging and make them joint owners of the financial institutions. This will not only enhance their access to finance but will also make them work for its success for enhancing effective housing development. 


\section{References}

Abdul, A.A. (2008). Time Lag in the Development of Urban Residential Plots in Kano Metropolis. An Unpublished M.Sc. Thesis, Geography Department, Bayero University Kano.

Adamu, E.O. (2007). The Private Development of Residential Land Subject to Statutory Title in Makurdi, Benue State, Nigeria. Unpublished M. Sc Thesis. Bayero University, Kano.

Adebayo, A.S. (2014). Local Government and the Challenges of Rural Development in Nigeria (1999 to date). IOSR Journal Of Humanities And Social Science. 19(4): 98-107

Adeniyi, E.O. (2007). Housing and the Construction Industry in Nigeria, Nigerian Institute of Social and Economic Research (NISER) Intec Printers, Ibadan.

African Monitor (2012). Rural Infrastructure in Africa: Unlocking the African Moment. Development Support Monitor - Paper series No.1, 2012.

Akeju A.A. (2007). Challenges to Providing Affordable Housing in Nigeria. Being a Paper Presented at the 2nd Emerging Urban Africa International Conference on Housing Finance in Nigeria, Held at Sehu Yar'adua Center Abuja, October 17-19, 2007.

Akpomuvie O. B. (2010). Self-Help as a Strategy for Rural Development in Nigeria: A Bottom-Up Approach. Journal of Alternative Perspectives in the Social Sciences. 2 (1): 88-111

Akpomuvie, B.O. (2010). Sustainable Rural Development in Nigeria through Microfinance: The Place of Women. African research review. 4 (2): 252-264

Aribigbola A. (2011). Housing Affordability as a Factor in the Creation of Sustainable Environment in Developing World: The example of Akure, Nigeria, Journal of Human Ecology, 35 (2), 121 - 131.

Aribigbola, A. (2008.). Housing Policy Formulation in Developing Countries: Evidence of Programme Implementation from Akure, Ondo State, Nigeria. Journal of Human Ecology, 23(2), 125-134.

Aworemi, J. R, Abdul-Azeez, I. A. \& Opoola, N. A. (2011,). An Appraisal of the Factors Influencing RuralUrban Migration in Some Selected Local Government Areas of Lagos State Nigeria. Journal of Sustainable Development, 4 (3).

Axton, Betz-Hamilton (2013). "How Does Culture Influences Housing Choices and Behaviors of Residents of the Pine Ridge Reservation? Preliminary Results" Proceedings of the Housing Education and Research Association Conference

Ayoola A. and Amole D. (2014). The Value of Housing among the Poor in Ilesa, Osun State Nigeria. Architecture Research. 4(1A): 45-54.

Beamish, J.D, Mc Cray, J.W, Weber, M.J, \& Brewer, G. (1989). Housing values of Southern Rural Households (Monograph of S-194 Southern Regional Technical Committee Serial No. 01-89). Auburn, AL: Auburn University.

Beer, A. and Tually, S. (2012). How should government respond to affordability problems in regional and rural housing markets? AHURI Research \& Policy Bulletin. Issue 154 May 2012 • ISSN 1445-3428
Bello, I.K. and Olatubara, C.O. (2014). An evaluation of the management of integrated township development in Ogun state. American Journal of Social and Management Sciences. 5 (2): 64-72.

Beyer, G.H. (1959). Housing and Personal Values. Cornell University Ithaca, NY: Housing Research Publication No.3.

Bourne, L.S. (2007) A Geography of Housing. Edward Arnold, London

Chatterjee, E. (2008) Urbanisation Trends and Problems of Urban Housing in Nigeria. Ibadan University Press, Ibadan.

Chiu, R. L. H. (2002). Socio-cultural sustainability of housing: A conceptual exploration; paper presented at the European Network of Housing Research (ENHR) Conference on Housing Cultures-Convergence and Divergence organized by the Europaforum Wien - Centre for Urban Dialogue and European Policy and the ENHR on 1-5 July 2002.

Deitz R. (2015) Housing Share of GDP Holds Constant. Eye on housing. NAHB. Retrieved from http://eyeonhousing.org/2015/03/housing-share-of-gdpholds-constant/

Ebadi, B., Ghoreishi, M.B. and Hashjin, N.M. (2015). Factors Affecting Functional Changes of Rural Settlements in Southwestern of Tehran in the Post-Islamic Revolution in Iran. Journal of Applied Sciences. 15 (7): 982-990.

Essendi, H. and Madise, N. (2014). Factors Influencing Perception of Development in Rural Kenya: A Structural Equation Modeling Approach. European Journal of research in social sciences. 2(4): 21-36

FAO corporate document repository (n.d) Guidelines on social analysis for rural area development planning. Retrieved from http://www.fao.org/docrep/t1660e/t1660e02.htm

Ferreras J. (2016) Real Estate GDP Now Represents Half Of Canada's Economic Growth. Business Canada. Retrieved from http://www.huffingtonpost.ca/2016/08/02/real-estategdp-canada_n_11309192.html.

Ibimilua A. F. and Ibitoye O.A. Housing Policy in Nigeria: An Overview. American International Journal of Contemporary Research. 5(2): 53-59.

Ijaiya, M.A., Lawal, W.A. and Osemene, O.F. (2014) Microfinance and Mortgage Financing In Nigeria: A Rural Experience. International Journal of Economics and Management Sciences. 1(10): 39-44.

Iwayemi, A. (2006). Nigeria's Oil Wealth: the Challenge of Sustainable Development in an Economy Dependent on Non-Renewable Natural Resources. University of Ibadan Postgraduate School 31st Interdisciplinary Research Discourse. Ibadan: University of Ibadan.

Jamini, D., Nori Zamanabadi, S.H., Jamshidi, A., \& Ebrahimi, M.S. (2014). Review and assessment of factors influencing villagers' satisfaction with rural housing (Case study: Avramanat region, Kermanshah Province). Journal of Research \& Rural Planning, 3(6), 1-15.

Jabaree, Yosef (2005), Culture and Housing Preferences in a Developing city, Environment and Behavior, 37 (1): 134-146. 
Jiboye, A. D. (2004). An assessment of the influence of socio-cultural factors on housing quality in Osogbo, Osun State, Nigeria, An unpublished M.Sc. Thesis, Department of Urban and Regional Planning, Obafemi Awolowo University, Ile-Ife.

Kolawole Y. (2015) Housing as tool for economic development. Vanguard. Retrieved from http://www.vanguardngr.com/2015/11/housing-as-toolfor-economic-development/

Lin, Shi (2005). Housing preferences of residents in Stellenbosch, South Africa. An application of the hedonic price model. Unpublished Master Dissertation, University of Stellenbosch, South Africa.

Lindamood, S. \& Hanna, SF. (1979). Housing, community and consumers: An introduction. St. Paul Minnesota West publishing company.

Makinde, O.O. (2015). Influences of socio-cultural experiences on residents' satisfaction in Ikorodu low-cost housing estate, Lagos state. Environmental Development Sustainability. 17:173-198

Maslow, A. (1954). Motivation and personality. New York, NY: Harper. pp. 92.

Morris, E. W., \& Winter, M. (1978). Housing, family, and society. New York: Wiley.

Nubi, O.T. (2008): Affordable housing delivery in Nigeria. The South African Foundation International Conference and Exhibition. Cape town, October: 1-18.

Ogu V.I. (1994) Rural housing quality in Nigeria: A case study from Imo State. Habitat International. 18 (3). 53-65.

Ogundahunsi D.S. \& Adejuwon S.A. (2014) Housing Condition and Health Relationships in Ijeda-Ijesa and Iloko-Ijesa, Osun State, Nigeria. Global Journal of Human-Social Science: B Geography, Geo-Sciences, Environmental Disaster Management. 14 (7): 1-8.

Okonjo-Iweala, N. (2014). Unleashing the Housing Sector in Nigeria and in Africa. Paper presented at the 6th Global Housing Finance Conference World Bank Headquarters, Washington, DC. Wednesday, 28th May, 2014

Olawepo, R.A. (2009) Evaluating Housing Problems through Participatory Rural Appraisal in Lokoja Nigeria. African research review. 3 (1): 77-96

Olayiwola, L. Adeleye, O. and Jiboye, A. (2006) Effect of Socio-Cultural factors on Housing Quality in Osogbo, Nigeria. CIB W107 Construction in Developing Countries International Symposium. "Construction in developing Economies: New Issues and Challenges” 18 20 January 2006, Santiago, Chile.

Olotuah, A. O. \& Bobadoye, S. A. (2009). Sustainable Housing Provision for the Urban Poor: A Review of Public Sector Intervention in Nigeria. The Built \& Human Environment Review, 2, 2009.

Olotuah, A.O. (2009). Demystifying the Nigerian urban housing question, Inaugural Lecture Series 53, Delivered at the Federal University of Technology Akure, March 10.

Omonigho T. O. (2013) Causes and Consequences of Rural-Urban Migration Nigeria: A Case Study of Ogun Waterside Local Government Area of Ogun State,
Nigeria. British Journal of Arts and Social Sciences, 16(1): 185-194.

Roske, M.D. (1983). Housing in Transition. New York: Holt, Rinehart and Winston Publications.

Shuaibu, U. (2016) Nigeria: The Imperative of Having Federal Ministry of Housing and Urban Development. Daily Trust, 30th May, 2016. Retrieved from http://allafrica.com/stories/201605301018.html

Shui, W., Bai, J., Zhang, S. and Chen, Y. (2014) Analysis of the Influencing Factors on Resettled Farmer's Satisfaction under the Policy of the Balance between Urban Construction Land Increasing and Rural Construction Land Decreasing: A Case Study of China's Xinjin County in Chengdu City. Sustainability. 6 (1) 8522-8535.

Spencer-Oatey, H. (2008) Culturally Speaking. Culture, Communication and Politeness Theory. 2nd edition. London: Continuum.

Spencer-Oatey, H. (2012). What is culture? A compilation of quotations. GlobalPAD Core Concepts. Available at GlobalPAD Open House

Thwala1, W.D. (2005). Employment Creation through the provision of Low cost housing in South Africa. Proceeding of the World Congress on Housing Transforming Housing Environments through Design. September 27-30, 2005, Pretoria, South Africa.

Toyobo A.E., Muili A.B. and Adetunji M.A. (2014). The relevance infrastructural facilities to rural housing development in Lagelu Local government, Oyo State, Nigeria. International NGO journals. 9 (3): 29 to 34.

Turner, J.F.C. (1972), ' 'Housing as a Verb', Freedom to Build, Turner J.F.C., \& Fichter R.(Eds.) Collier Macmillan, New York,143-175.

Van der Heijden, H. (2013) West European housing systems in a comparative perspective, Amsterdam: IOS Press.

Vanguard (2016, June 27) IGR: 36 states generate N682bn. Vanguard. Retrieved from http://www.vanguardngr.com/2016/06/igr-36-statesgenerate-n682bn/

Wahab, K. A. (1993), Industrialisation and Urbanization. Being the Text of a Paper Presented at a Workshop organized by FEDAN/LEAD Nigeria, Lagos.

Wardrip, K. Williams, L and Hague, S. (2011), The Role of Affordable Housing in Creating Jobs and Stimulating Local Economic Development: A Review of the Literature. Washington, DC :Center for Housing Policy. Retrieved from http://www2.nhc.org/media/files/Housing-andEconomic-Development-Report-2011.pdf

World Bank (2015), International Development Association Program Document for a Proposed Development Policy Credit in the Amount of SDR 53.3 Million (US\$75 Million Equivalent) to the Federal Republic of Nigeria for a Edo State Fiscal Improvement and Service Delivery Development Policy Operation. Retrieved from http://documents.worldbank.org/curated/en/8800914680 98970115/text/949940PGD0P151010Box391420B00OU O090.txt 